\title{
BLACK OAT AND RYEGRASS INOCULATED WITH Azospirillum brasilense IN CROP-LIVESTOCK SYSTEM ${ }^{1}$
}

\author{
MARCOS DA SILVA BRUM ${ }^{2 *}$, VINICIUS DOS SANTOS CUNHA ${ }^{3}$, THOMAS NEWTON MARTIN $^{3 *}$, \\ PEDRO GARDIN ALESSIO ${ }^{3}$, GUILHERME ARISMENDI ALMEIDA ${ }^{3}$
}

\begin{abstract}
The success of the integrated crop-livestock system depends on the correct pasture management, particularly regarding nitrogen fertilization and grazing intensity. The objective of this study was to evaluate the total production of forage and the proportion of the botanical and structural components of black oat and annual ryegrass mixture. The experimental design was randomized blocks with three replicates and the treatments were arranged in a three-factorial scheme: seed inoculation (with and without Azospirillum brasilense inoculation), grazing management (conventional grazing, where the animals were kept in pasture with no control of pasture height; 30, 20 and $10 \mathrm{~cm}$ at the end of grazing, and a control without grazing), and nitrogen fertilization $\left(0,50\right.$ and $100 \mathrm{~kg}$ nitrogen ha $\left.{ }^{-1}\right)$. In treatments with pasture heights where grazing ended at 30,20 and $10 \mathrm{~cm}$, the height was monitored and biomass was collected when the animals entered and exited the plots. Manual separation of the components was used to determine the dry mass of green leaves, stems, senescent material and inflorescence. Total dry mass production was obtained based on the initial forage mass plus the daily accumulation rates. The proportion of structural components varied according to the different grazing managements, nitrogen doses and inoculation with Azospirillum brasilense. Biomass production of black oat and ryegrass mixture was increased by nitrogen application and Azospirillum brasilense inoculation.
\end{abstract}

Keywords: Nitrogen fertilization. Grazing heights. Inoculation.

\section{AVEIA PRETA E AZEVÉM INOCULADAS COM Azospirillum brasilense EM SISTEMA LAVOURA- PECUÁRIA}

RESUMO - O sucesso do sistema de integração lavoura-pecuária depende do correto manejo da pastagem, principalmente quanto às alturas de manejo do pastejo e adubação. Objetivou-se com esta pesquisa avaliar a produção de forragem e a proporção dos componentes botânicos e estruturais de uma pastagem de aveia preta e azevém. Os tratamentos foram organizados em um trifatorial: inoculação de sementes (com e sem inoculação com a bactéria Azospirillum brasilense), manejo de pastejo (pastejo convencional, onde os animais permaneciam na pastagem sem um controle da altura da pastagem, altura da pastagem na saída dos animais de 30,20 e $10 \mathrm{~cm}$ e uma testemunha sem pastejo), e o fator adubação nitrogenada (0, $50 \mathrm{e} 100 \mathrm{~kg}$ de nitrogênio $\left.\mathrm{ha}^{-1}\right)$. Foi coletada a massa de forragem presente em cada tratamento no momento da entrada e saída dos animais do pastejo e por meio de separação manual dos componentes determinou-se a massa seca de lâminas foliares verdes, massa seca de colmos, massa seca de material senescente, massa seca de inflorescência. A produção total de matéria seca foi obtida pela massa de forragem inicial acrescida das taxas de acúmulo diárias. As proporções dos componentes estruturais variaram em função dos diferentes manejos de pastejo, doses de nitrogênio e inoculação com $A$. brasilense. A produção de biomassa da pastagem de aveia preta e azevém foi incrementada pela aplicação de nitrogênio e com a inoculação de A. brasilense, sendo possível realizar a substituição do nitrogênio mineral pelo uso de $A$. brasilense.

Palavras-chave: Adubação nitrogenada. Alturas de pastejo. Inoculação.

\footnotetext{
*Corresponding author

${ }^{1}$ Received for publication in $02 / 17 / 2020$; accepted in $03 / 24 / 2021$.

Paper extracted from the doctoral thesis of the first author.

${ }^{2}$ NPR Fertizantes LTDa, Santa Maria, RS, Brazil, marcossbrum@yahoo.com.br -ORCID: 0000-0002-9950-7738.

${ }^{3}$ Crop Science Departament, Universidade Federal de Santa Maria, Santa Maria, RS, Brazil, vinicius_scunha@hotmail.com - ORCID: 0000 -0002-8022-6821, martin.ufsm@gmail.com -ORCID: 0000-0003-4549-3980, pedrogalessio98@gmail.com -ORCID: 0000-0003-04747884, almeidaarismendi@gmail.com - ORCID: 0000-0002-4643-1717.
} 


\section{INTRODUCTION}

The integration between crop and livestock $(\mathrm{CLI})$ is a system with greater sustainability (KUNRATH et al., 2014) and more intensive. In southern Brazil, black oat and ryegrass (winter) and soybean and corn (summer) crop are used. CLI improves soil quality by accumulating more organic matter and cycling nutrients; aggregating the soil (SOUZA et al., 2010); promoting efficiency in the use of fertilizers; increasing pasture production (CASSOL et al., 2011); interrupting the cycle of some diseases, pests and weeds; improving animal performance and reducing costs (BALBINOT et al., 2009). Excessive use of nitrogen fertilizers increases costs and causes damage to the environment through nitrate leaching in watercourses (WALKER et al., 2012). Biological nitrogen fixation aims to reduce costs, mitigate environmental impacts and promote greater plant growth and production gains (FILGUEIRAS; MENESES, 2015).

Bacteria of the genus Azospirillum are classified as symbiont bacteria, contributing to the improvement of crop yield (AON et al., 2015; AAZADI et al., 2014). These bacteria are capable of fixing nitrogen and producing plant growth hormones such as gibberellins, auxins and cytokinins (HUNGRIA; NOGUEIRA; ARAUJO, 2015). It is an alternative to reduce or supplement fertilization with mineral $\mathrm{N}$ in grass crops. Kurepin, Zaman and Pharis (2014) report that inoculation with $A$. brasilense increases grass biomass by $25 \%$. For corn, Schaefer et al. (2019) and Brum et al. (2016) verified that the production of shoot biomass, yield and thousandgrain weight were higher due to inoculation of seeds with $A$. brasilense. In wheat, it was found that $A$. brasilense improves the initial characteristics of plant development, but these effects are reduced over time (KAZI et al., 2016; PICCININ et al., 2013). Increments in grass yield have been reported in some studies with the use of Azospirillum brasilense (MULLER et al., 2016; DOMINGUES NETO et al., 2014). However, research using this bacterium in cold-season grasses is limited. For oats, Bilal et al. (2017) observed increases in dry mass and crude protein yield when using $A$. brasilense as a substitute for nitrogen.

The objective of this study was to evaluate the total production of forage and the structural components of black oat and ryegrass managed under different grazing heights, nitrogen doses and seed inoculation with $A$. brasilense in a croplivestock integration system.

\section{MATERIAL AND METHODS}

The experiment was conducted in 2012 and 2013, in Santa Maria, RS, Brazil, at the geographic coordinates $29^{\circ} 41^{\prime} 51.07^{\prime \prime} \mathrm{S}$ and $54^{\circ} 022^{\prime} 30.42^{\prime \prime} \mathrm{W}$, at an altitude of 195 meters. The climate is Cfa, subtropical humid, according to Köppen's classification. The experimental area was 0.36 ha, in a crop-livestock integration system, with pasture formed by an intercropping of black oats and ryegrass in the winter period and with corn and soybean in subsequent summers. In 2012, common cultivars (black oat and ryegrass) were used. In 2013, the black oat cultivar IAPAR 61 and the ryegrass cultivar BRS Ponteio were used. The soil of the experimental area is classified as Argissolo Vermelho distrófico arênico (Ultisol) (EMBRAPA, 2006). The area was cultivated with ryegrass, soybean and millet in the periods prior to sowing of the experiments (May 17, 2013, both years).

The number of suitable seeds per $\mathrm{m}^{2}$ was 400 seeds ( 300 of black oats +100 of ryegrass) in both years. The experimental design was randomized blocks with three replicates and the treatments were arranged in a trifactorial scheme (inoculation of seeds (2) x grazing management (5) x nitrogen application (3)). Black oat and ryegrass seeds were subjected or not to inoculation with $A$. brasilense (strains Abv5 and Abv6), using liquid inoculant (AZO TOTAL $®$ ) at a concentration of $2 \times 10^{8}$ colony-forming units per $\mathrm{mL}$ of product. The managements were carried out as follows: (I) conventional grazing (CG), where the animals remained in the pasture throughout the experimental period with no control of pasture height, (II) pasture height at the exit of the animals of $30 \mathrm{~cm}$ (H30), (III) - pasture height at the exit of the animals of $20 \mathrm{~cm}$ (H20), (IV) - pasture height at the exit of the animals of $10 \mathrm{~cm}(\mathrm{H} 10)$ and (V) - No grazing (NG). Fertilization management was as follows: without nitrogen fertilization; $50 \mathrm{~kg} \mathrm{ha}^{-1}$ nitrogen $(\mathrm{N})$ and $100 \mathrm{~kg} \mathrm{ha}^{-1}$ of $\mathrm{N}$. In treatments with dose of $50 \mathrm{~kg} \mathrm{ha}^{-1}$, the application was carried out broadcast in a single time, whereas in treatments with dose of $100 \mathrm{~kg} \mathrm{ha}^{-1}$, the dose was split into two applications. The $\mathrm{N}$ source used was urea $(45 \% \mathrm{~N})$. In 2012 and 2013, the first application of $\mathrm{N}$ occurred at the beginning of tillering, at the dose of $50 \mathrm{~kg}$ of $\mathrm{N} \mathrm{ha}^{-1}$. At this time, $\mathrm{N}$ was applied to the plots that would receive doses of 50 and $100 \mathrm{~kg}$ of $\mathrm{N} \mathrm{ha}^{-1}$. The second application of $50 \mathrm{~kg}$ of $\mathrm{N} \mathrm{ha}^{-1}$ was performed in the plots that would receive $100 \mathrm{~kg}$ of $\mathrm{N} \mathrm{ha}{ }^{-1}$. Each experimental unit had dimensions of $8 \times 4 \mathrm{~m}$, totaling an area of $32 \mathrm{~m}^{2}$.

The animals used for grazing were Corriedale sheep, with an average age of one year, with five sheep per experimental unit. For the heights of the exit of the animals of 10,20 and $30 \mathrm{~cm}$, the rotational grazing method was adopted, and the animals remained in the plots for the time necessary to reach the desired heights, ranging from two to five days. The interval between grazing events was 28 days. In 2012, grazing occurred twice because of a delay for the pasture to reach an initial forage mass 
of around $1500 \mathrm{~kg} \mathrm{ha}^{-1}$. In 2013, grazing was carried out three times. For the characterization of pasture height, it was monitored by the "sward stick" ruler method.

Forage mass was determined in each plot by means of cuts with scissors, close to the ground, in an area delimited by a $0.25 \mathrm{~m}^{2}$ frame. Forage mass was determined in each experimental unit at the entry and exit of the animals in each grazing period. From the samples obtained from the cuts, the botanical and morphological composition of the pasture was determined by manually separating the structural components: leaf (blade), stem (leaf sheath + stem), senescent material and inflorescence. All samples were dried in an oven with forced air circulation at $60{ }^{\circ} \mathrm{C}$, until reaching constant weight, and subsequently weighed. The following parameters were evaluated: dry mass of green leaves (DMGL), dry mass of stems (DMS), dry mass of senescent material (DMSM), dry mass of inflorescence (DMI) and total dry mass (TDM).

In treatments with different pasture heights (H10, H20 and H30), the evaluations of the dry mass accumulation rate $\left(\mathrm{kg} \mathrm{ha}^{-1} \mathrm{day}^{-1}\right)$ were performed in each plot, based on the difference in forage mass at the entry of the animals during the period (X) and forage mass at the exit of the animals during the period (X-1), divided by the number of days of the period. In treatments with conventional grazing, dry mass accumulation rates were determined with the aid of grazing exclusion cages, using one cage in each experimental unit. The total dry mass production was obtained based on the initial forage mass plus the daily accumulation rates multiplied by the number of days of the period. The data were subjected to analysis of variance and, when significant, the means were compared by the Duncan test, with $5 \%$ probability of error.

\section{RESULTS AND DISCUSSION}

The structural components of the forage mass were influenced by the application of nitrogen $(\mathrm{N})$ in the first evaluation period (Table 1). Higher DMGL, DMS and TDM were observed in treatments that received $50 \mathrm{~kg} \mathrm{ha}^{-1}$ of $\mathrm{N}$. The DMGL of the black oat-ryegrass intercropping showed an increase of $7.72 \mathrm{~kg} \mathrm{ha}^{-1}$ of DM for each $\mathrm{kg}$ of $\mathrm{N}$ applied. This result should be emphasized, because the application of $50 \mathrm{~kg}$ of $\mathrm{N} \mathrm{ha}{ }^{-1}$ in the tillering stage led to increments of $386 \mathrm{~kg} \mathrm{ha}^{-1}$ for DMGL and $633 \mathrm{~kg} \mathrm{ha}^{-1}$ for TDM. In a practical way, $\mathrm{N}$ application is fundamental for pasture management, as it allows the pasture to produce the same amount of leaves in a shorter period of time when compared to pasture without $\mathrm{N}$, being possible to reduce the sowing interval until the first grazing.

Table 1. Average values for the components dry mass of green leaf blades (DMGL, $\mathrm{kg} \mathrm{ha}^{-1}$ ), dry mass of stems $\left(\mathrm{DMS}, \mathrm{kg} \mathrm{ha}^{-1}\right.$ ), leaf/stem ratio (LSR), dry mass of senescent material (DMSM, $\mathrm{kg} \mathrm{ha}^{-1}$ ), dry mass of inflorescence (DMI, $\left.\mathrm{kg} \mathrm{ha}^{-1}\right)$, total dry mass $\left(\mathrm{TDM}, \mathrm{kg} \mathrm{ha}^{-1}\right)$ and height $(\mathrm{H}, \mathrm{cm})$ of a pasture of black oat and ryegrass under different managements in a crop-livestock integration system.

\begin{tabular}{|c|c|c|c|c|c|c|}
\hline \multicolumn{7}{|c|}{ Entry first grazing } \\
\hline Factors & Treatments & DMGL & DMS & LSR & DMSM & TDM \\
\hline \multirow{2}{*}{$\begin{array}{l}\mathrm{N} \text { doses } \\
\left(\mathrm{kg} \mathrm{ha}^{-1}\right)\end{array}$} & 0 & $809.92 b^{*}$ & $336.11 \mathrm{~b}$ & 2.41 & 95.29 & $1231.07 \mathrm{~b}$ \\
\hline & 50 & $1196.02 \mathrm{a}$ & $562.47 \mathrm{a}$ & 2.13 & 105.84 & $1864.33 \mathrm{a}$ \\
\hline \multirow{2}{*}{$\begin{array}{l}\text { Inoculation } \\
\text { Azospirillum }\end{array}$} & Without & 928 & 400.57 & 2.32 & 96.57 & 1411.48 \\
\hline & With & 949.25 & 422.54 & 2.25 & 101.04 & 1472.83 \\
\hline \multicolumn{7}{|c|}{ Exit first grazing } \\
\hline & & DMGL & DMS & DMSM & TDM & $\mathrm{H}$ \\
\hline \multirow{3}{*}{$\begin{array}{c}\text { Grazing } \\
\text { management }\end{array}$} & $30 \mathrm{~cm}$ & $797.02 \mathrm{a}^{*}$ & $684.18 \mathrm{a}$ & 96.73 & $1577.93 \mathrm{a}$ & $23.55 \mathrm{a}$ \\
\hline & $20 \mathrm{~cm}$ & $522.51 \mathrm{~b}$ & $474.00 \mathrm{~b}$ & 101.04 & $1097.56 \mathrm{~b}$ & $19.95 \mathrm{~b}$ \\
\hline & $10 \mathrm{~cm}$ & $251.53 \mathrm{c}$ & $308.44 \mathrm{c}$ & 94.31 & $641.60 \mathrm{c}$ & $12.00 \mathrm{c}$ \\
\hline \multirow{2}{*}{$\begin{array}{l}\mathrm{N} \text { doses } \\
\left(\mathrm{kg} \mathrm{ha}^{-1}\right)\end{array}$} & 0 & $499.82 \mathrm{~b}$ & $438.68 \mathrm{~b}$ & 96.87 & $1029.02 \mathrm{~b}$ & $18.08 \mathrm{~b}$ \\
\hline & 50 & $571.42 \mathrm{a}$ & $589.27 \mathrm{a}$ & 98.35 & $1259.04 \mathrm{a}$ & $19.34 \mathrm{a}$ \\
\hline \multirow{2}{*}{$\begin{array}{l}\text { Inoculation } \\
\text { Azospirillum }\end{array}$} & Without & 516.95 & 496.55 & 95.27 & 1100.31 & 18.82 \\
\hline & With & 530.43 & 481.20 & 99.45 & 1111.08 & 18.18 \\
\hline
\end{tabular}

*Means not followed by the same letter differ at $5 \%$ probability of error by Duncan's test. 
In ryegrass pasture, Pellegrini et al. (2010) verified that $\mathrm{N}$ increases the forage mass produced and DMGL shows an increasing linear behavior of $1.28 \mathrm{~kg} \mathrm{ha}^{-1}$ of DM for each $\mathrm{kg}$ of $\mathrm{N}$ applied in the pasture. The values found for DMGL ranged from 515.0 to $814.6 \mathrm{~kg} \mathrm{ha}^{-1}$ of DM for the $\mathrm{N}$ doses of 0 and $225 \mathrm{~kg} \mathrm{ha}^{-1}$, respectively. When $\mathrm{N}$ is added, the plant increases the number of active meristems and density of tillers and maintains the growth of leaves. At the beginning of the second grazing (Table 2), it was possible to observe the influence of grazing management on pasture structure, and the treatments with heights of 30 and $20 \mathrm{~cm}$ showed higher values of TDM. However, they had lower leaf/stem ratio (LSR) values in comparison to those with more intense grazing.

Table 2. Dry mass of green leaf blades (DMGL, $\mathrm{kg} \mathrm{ha}^{-1}$ ), dry mass of stems (DMS, $\mathrm{kg} \mathrm{ha}^{-1}$ ), dry mass of senescent material $\left(\mathrm{DMSM}, \mathrm{kg} \mathrm{ha}^{-1}\right)$, dry mass of inflorescence (DMI, $\mathrm{kg} \mathrm{ha}^{-1}$ ), total dry mass (TDM, $\mathrm{kg} \mathrm{ha}^{-1}$ ) and height $(\mathrm{H}, \mathrm{cm})$ in post-grazing residue of a pasture of black oat and ryegrass under different managements in a crop-livestock integration system.

\begin{tabular}{|c|c|c|c|c|c|c|c|}
\hline \multirow[b]{2}{*}{ Factors } & \multicolumn{7}{|c|}{ Entry second grazing } \\
\hline & Treatments & DMGL & DMS & LSR & DMSM & DMI & TDM \\
\hline \multirow{4}{*}{$\begin{array}{c}\text { Grazing } \\
\text { management }\end{array}$} & $\mathrm{CG}$ & $585.60 \mathrm{c}$ & $757.11 \mathrm{c}$ & $0.77 \mathrm{a}$ & $338.95 \mathrm{~b}$ & $158.44 \mathrm{c}$ & $1840.11 \mathrm{c}$ \\
\hline & $30 \mathrm{~cm}$ & $716.64 \mathrm{~b}$ & $2283.73 \mathrm{a}$ & $0.31 \mathrm{~b}$ & $464.00 \mathrm{a}$ & $523.31 \mathrm{a}$ & $3987.68 \mathrm{a}$ \\
\hline & $20 \mathrm{~cm}$ & $714.53 \mathrm{~b}$ & $1646.00 \mathrm{~b}$ & $0.43 \mathrm{~b}$ & $273.97 \mathrm{~b}$ & $319.11 \mathrm{~b}$ & $2953.62 b$ \\
\hline & $10 \mathrm{~cm}$ & $878.18 \mathrm{a}$ & $1063.93 \mathrm{c}$ & $0.83 \mathrm{a}$ & $155.42 \mathrm{c}$ & $127.44 \mathrm{c}$ & $2224.97 \mathrm{c}$ \\
\hline & 0 & $543.27 \mathrm{~b}$ & $1218.65 \mathrm{~b}$ & $0.45 \mathrm{~b}$ & $310.767 \mathrm{ab}$ & $253.38 \mathrm{ab}$ & $2326.06 \mathrm{~b}$ \\
\hline $\mathrm{N}$ doses & 50 & $828.28 \mathrm{a}$ & $1451.41 \mathrm{ab}$ & $0.57 \mathrm{a}$ & $237.867 \mathrm{~b}$ & $209.61 \mathrm{~b}$ & $2727.18 \mathrm{~b}$ \\
\hline$\left(\mathrm{kg} \mathrm{ha}^{-1}\right)$ & 100 & $799.67 \mathrm{a}$ & $1643.01 \mathrm{a}$ & $0.49 \mathrm{~b}$ & $375.633 \mathrm{a}$ & $383.23 \mathrm{a}$ & $3201.55 \mathrm{a}$ \\
\hline Inoculation & Without & 684.07 & 1407.78 & 0.49 & 281.71 & 294.43 & 2668.00 \\
\hline \multirow[t]{4}{*}{ Azospirillum } & With & 763.41 & 1467.60 & 0.52 & 334.46 & 269.72 & 2835.20 \\
\hline & \multicolumn{7}{|c|}{ Exit second grazing } \\
\hline & \multirow{2}{*}{\multicolumn{2}{|c|}{ Dry mass of stems (DMS) }} & \multicolumn{5}{|c|}{ Grazing Management } \\
\hline & & & \multicolumn{2}{|c|}{$30 \mathrm{~cm}$} & $20 \mathrm{~cm}$ & \multicolumn{2}{|r|}{$10 \mathrm{~cm}$} \\
\hline Inoculation & \multicolumn{2}{|c|}{ Without } & \multicolumn{2}{|c|}{$1682.93 \mathrm{a} \mathrm{A}$} & 1331.73 a B & \multicolumn{2}{|c|}{713.46 a C } \\
\hline \multirow{2}{*}{ Azospirillum } & \multicolumn{2}{|c|}{ With } & \multicolumn{2}{|c|}{$1871.20 \mathrm{a} \mathrm{A}$} & 991.68 b B & \multicolumn{2}{|c|}{483.86 a C } \\
\hline & \multicolumn{7}{|c|}{ Total dry mass (TDM) } \\
\hline Inoculation & \multicolumn{2}{|c|}{ Without } & $2362.1^{\prime}$ & & 1986.62 a B & & 71.95 a C \\
\hline Azospirillum & & & 2614.5 & & $1623.33 \mathrm{~b} \mathrm{~B}$ & & 11.77 a C \\
\hline & & Dry & ass of senes & at materi & (DMSM) & & \\
\hline & $\mathrm{Nc}$ & & $0 \mathrm{~kg}$ of & $\mathrm{ha}^{-1}$ & $50 \mathrm{~kg}$ of $\mathrm{N} \mathrm{ha}^{-1}$ & 100 & ${\mathrm{~kg} \text { of } \mathrm{N} \mathrm{ha}^{-1}}^{-1}$ \\
\hline Inoculation & Wit & & 296.57 & & 279.60 a B & & 04.17 a A \\
\hline Azospirillum & & & 308.53 & & 336.88 a A & & $72.53 \mathrm{~b} \mathrm{~A}$ \\
\hline & Grazing $m$ & nent & $\mathrm{DMC}$ & & DMI & & $\mathrm{H}$ \\
\hline & & & 134. & & $147.04 \mathrm{a}$ & & $25.93 \mathrm{a}$ \\
\hline $\begin{array}{c}\text { Grazing } \\
\text { management }\end{array}$ & & & 176. & & $143.49 \mathrm{a}$ & & $20.45 b$ \\
\hline & & & 172. & & $75.22 \mathrm{~b}$ & & $11.07 \mathrm{c}$ \\
\hline & & & 130. & & 129.93 & & 19.03 \\
\hline $\mathrm{N}$ doses & & & 177. & & 111.18 & & 18.57 \\
\hline$\left(\mathrm{kg} \mathrm{ha}^{-1}\right)$ & & & 175. & & 124.64 & & 19.86 \\
\hline Inoculation & Wit & & 159. & & 110.90 & & 19.44 \\
\hline Azospirillum & & & 162. & & 132.93 & & 18.86 \\
\hline
\end{tabular}

*Different uppercase letters in the row and different lowercase letters in the column indicate difference between treatments at $5 \%$ probability level by the Duncan test. 
As verified in the first evaluation, the DMGL values were higher for the treatments with the use of 100 and $50 \mathrm{~kg} \mathrm{ha}^{-1}$ of $\mathrm{N}$. On the other hand, TDM was superior in the treatment with $100 \mathrm{~kg} \mathrm{ha}^{-1}$ of $\mathrm{N}$. In the second grazing, according to the regression equation $(\mathrm{Y}=8.759 \mathrm{X}+2313.9)$, there was an increase in forage mass (TDM) of $8.75 \mathrm{~kg} \mathrm{ha}^{-1}$ of $\mathrm{DM}$ for each $\mathrm{kg}$ of $\mathrm{N}$ applied.

There was an increase in residual TDM from the first to the second grazing for the three grazing management heights. Such increase results from the increase in DMS, decrease in DMGL and decrease in water content in plant tissues. After the second grazing (Table 2), differences were verified in DMS for the different grazing heights, which did not occur for DMGL. Due to the increased participation of black oat stems from the first to the second grazing, this was the component that most contributed to TDM. For leaves, there were no differences between grazing heights because of their low participation in TDM.

The total dry mass production (DMP, $\mathrm{kg} \mathrm{ha}^{-1}$ ) was higher when $100 \mathrm{~kg}$ of $\mathrm{N} \mathrm{ha}^{-1}$ was applied, followed by the application of $50 \mathrm{~kg}$ of $\mathrm{N} \mathrm{ha}^{-1}$ and the control. With the application of $100 \mathrm{~kg}$ of $\mathrm{N} \mathrm{ha}^{-1}$, there was an increase of $1,665.18 \mathrm{~kg}$ of $\mathrm{DM} \mathrm{ha}{ }^{-1}$ compared to the control without nitrogen fertilization. This corresponds to an increase of $16.65 \mathrm{~kg}$ of DM ha ${ }^{-1}$ for each $\mathrm{kg}$ of $\mathrm{N}$ applied in the pasture (regression equation: $\mathrm{Y}=16.652 \mathrm{X}+$ 3497.2)

Pellegrini et al. (2010) obtained similar results in which each $\mathrm{kg}$ of $\mathrm{N}$ applied caused an increase of $15.83 \mathrm{~kg} \mathrm{ha}^{-1}$ in the dry mass of ryegrass. Cassol et al. (2011) state that the use of nitrogen fertilization promotes an increase in the forage production of black oat and ryegrass pasture, which increases the support capacity of the pasture.

The production with inoculation was $4582.30 \mathrm{~kg} \mathrm{ha}^{-1}$, higher than that obtained without inoculation $\left(4077.20 \mathrm{~kg} \mathrm{ha}^{-1}\right)$. There was an increase of $505 \mathrm{~kg} \mathrm{ha}^{-1}$ in DMP under inoculation of A. brasilense. Considering that there is an increase of $16.65 \mathrm{~kg}$ of $\mathrm{DM} \mathrm{ha}{ }^{-1}$ for each $1 \mathrm{~kg}$ of mineral $\mathrm{N}$ applied in the pasture, the inoculation of A. brasilense replaced $30.33 \mathrm{~kg} \mathrm{ha}^{-1}$ of mineral $\mathrm{N}$ (67.4 $\mathrm{kg}$ of urea). Due to the low cost of the inoculant, and the DMP response observed in this study, it can be inferred that the use of inoculation with Azospirillum brasilense in black oats and ryegrass can replace part of the fertilization with mineral nitrogen.

The values of DMGL and TDM showed a distinct behavior as a function of inoculation, $\mathrm{N}$ doses and grazing management practiced in the previous year. The values of DMGL and TDM were higher when $50 \mathrm{~kg}$ of $\mathrm{N} \mathrm{ha}^{-1}$ was used and the seeds were inoculated, regardless of the uniform grazing management of the previous year when nitrogen application was used. The response varied according to the grazing management applied in the previous year. Similar behavior was verified for DMGL and TDM, prior to the third grazing (Table 5).

Thus, inoculation with $A$. brasilense may have provided an additional amount of $\mathrm{N}$, promoting higher TDM. On the other hand, DMS values varied according to nitrogen doses and grazing management. Regarding inoculation, the structural components of the pasture varied according to grazing management and nitrogen doses, and there was no standard response regarding the use of inoculation. For DMSM, in the treatments CG, 20 $\mathrm{cm}$ and $\mathrm{NG}$ and without nitrogen, the use of inoculation allowed lower values of senescent material in the pasture (Table 3 ).

DMGL was higher in the treatment of $30 \mathrm{~cm}$; however, there was lower LSR due to the greater accumulation of stems (DMS) in this treatment. This result is in accordance with Baggio et al. (2008), who report that in situations of moderate grazing (lower frequency and intensity of defoliation), greater grazing management heights generate greater participation of stems in black oat and ryegrass pasture. DMGL was higher when $100 \mathrm{~kg}$ of $\mathrm{N} \mathrm{ha}^{-1}$ were applied, compared to doses of 0 and $50 \mathrm{~kg}$ of $\mathrm{N} \mathrm{ha}^{-1}$, with no effect of inoculation on DMGL. The highest values of DMS, DMSM, DMI and TDM were found in treatments with $30 \mathrm{~cm}$ grazing management height, a consequence of the higher residual dry mass left after the first grazing.

There was a triple interaction for pasture height before the entry of the animals, for the first, second and third grazing. For the first grazing, an increase in pasture height was observed when $50 \mathrm{~kg}$ $\mathrm{ha}^{-1}$ of $\mathrm{N}$ were applied, in most of the grazing managements of the previous year (Table 4). Before the second and third grazing, the values of entry heights were influenced by the management of exit heights of the previous grazing (Tables 4 and 5). The greatest pasture heights were verified when $100 \mathrm{~kg} \mathrm{ha}^{-1}$ of $\mathrm{N}$ were applied in most treatments. The heights did not respond uniformly to inoculation, varying according to grazing management and $\mathrm{N}$ doses applied. In this case, it is verified that pasture height did not increase with the inoculation of $A$. brasilense. 
M. S. BRUM et al.

Table 3. Dry mass of green leaf blades (DMGL, $\mathrm{kg} \mathrm{ha}^{-1}$ ), dry mass of stems (DMS, $\mathrm{kg} \mathrm{ha}^{-1}$ ), dry mass of senescent material $\left(\mathrm{DMSM}, \mathrm{kg} \mathrm{ha}^{-1}\right)$, total dry mass $\left(\mathrm{TDM}, \mathrm{kg} \mathrm{ha}^{-1}\right)$ and height $(\mathrm{H}, \mathrm{cm})$ of a pasture of black oats and ryegrass under different managements in a crop-livestock integration system (entry of the first grazing, year 2013).

\begin{tabular}{|c|c|c|c|c|c|c|}
\hline \multicolumn{7}{|c|}{ DMGL } \\
\hline \multirow[t]{2}{*}{ Inoculation } & \multirow{2}{*}{$\begin{array}{c}\mathrm{N} \text { doses } \\
\left(\mathrm{kg} \text { of } \mathrm{N} \mathrm{ha}^{-1}\right)\end{array}$} & \multicolumn{5}{|c|}{ Grazing Management } \\
\hline & & CG & $30 \mathrm{~cm}$ & $20 \mathrm{~cm}$ & $10 \mathrm{~cm}$ & No grazing \\
\hline \multirow{2}{*}{ Without Azospirillum } & 0 & $* * \beta 521.99 \mathrm{BC}$ & $* \beta 323.34 \mathrm{C}$ & $\alpha 846.29$ a A & $\alpha 657.79 \mathrm{AB}$ & $\beta 605.30 \mathrm{~B}$ \\
\hline & 50 & $\alpha 742.73$ a A & $\alpha 761.23 \mathrm{~A}$ & $\beta 687.90 \mathrm{AB}$ & $\beta 537.25 \mathrm{~b} \mathrm{~B}$ & $\alpha 693.49 \mathrm{~b} \mathrm{AB}$ \\
\hline \multirow{2}{*}{ With Azospirillum } & 0 & $\beta 362.70 \mathrm{~B}$ & $\beta 351.43 \mathrm{~B}$ & $\beta 540.71 \mathrm{~b} \mathrm{AB}$ & $706.99 \mathrm{~A}$ & $\beta 477.22 \mathrm{AB}$ \\
\hline & 50 & $\alpha 498.29 \mathrm{~b} \mathrm{C}$ & $\alpha 674.60 \mathrm{~B}$ & $\alpha 829.01 \mathrm{AB}$ & 726.64 a B & $\alpha 908.85$ a A \\
\hline \multicolumn{7}{|c|}{ DMS } \\
\hline & 0 & $\beta 142.22 \mathrm{AB}$ & $\beta 106.90 \mathrm{~B}$ & $\beta 151.90 \mathrm{AB}$ & $\alpha 255.76 \mathrm{~A}$ & $\alpha 233.55 \mathrm{~A}$ \\
\hline & 50 & $\alpha 191.48 \mathrm{~A}$ & $\alpha 214.64 \mathrm{~A}$ & $\alpha 234.03 \mathrm{~A}$ & $\beta 188.03 \mathrm{~A}$ & B $190.08 \mathrm{~A}$ \\
\hline \multicolumn{7}{|c|}{ DMSM } \\
\hline \multirow{2}{*}{ Without Azospirillum } & 0 & $\alpha 184.10$ a $\mathrm{A}$ & $60.97 \mathrm{C}$ & $\alpha 104.06$ a B & $\beta 39.70 \mathrm{C}$ & $\alpha 215.78$ a A \\
\hline & 50 & $\beta 41.57 \mathrm{~B}$ & $50.98 \mathrm{~B}$ & $\beta 67.48 \mathrm{~B}$ & $\alpha 55.04 \mathrm{~B}$ & B $119.42 \mathrm{~A}$ \\
\hline \multirow{2}{*}{ With Azospirillum } & 0 & $66.08 \mathrm{~b} \mathrm{AB}$ & $\alpha 85.47 \mathrm{~A}$ & $\beta 35.26 \mathrm{~b} \mathrm{BC}$ & $\beta 12.68 \mathrm{C}$ & 89.86 b A \\
\hline & 50 & $61.65 \mathrm{~B}$ & $\beta 58.19 \mathrm{~B}$ & $\alpha 64.97 \mathrm{~B}$ & $\alpha 51.56 \mathrm{~B}$ & $94.95 \mathrm{~A}$ \\
\hline \multicolumn{7}{|c|}{ TDM } \\
\hline \multirow{2}{*}{ Without Azospirillum } & 0 & $\beta 878.00$ a $\mathrm{A}$ & $\beta 456.12 \mathrm{~B}$ & 1098.26 a A & $\alpha 1163.66 \mathrm{~A}$ & $\alpha 1110.34$ a A \\
\hline & 50 & $\alpha 1095.37$ a A & $\alpha 981.63 \mathrm{~A}$ & $1122.93 \mathrm{~A}$ & $\beta 720.04 \mathrm{~b} \mathrm{~B}$ & $\beta 961.23 \mathrm{~b} \mathrm{~A}$ \\
\hline \multirow{2}{*}{ With Azospirillum } & 0 & $\beta 541.33$ b B & $\beta 578.90 \mathrm{~B}$ & $\beta 731.87 \mathrm{~b} \mathrm{AB}$ & B 937.22 A & $\beta 744.93 \mathrm{~b} \mathrm{AB}$ \\
\hline & 50 & $\alpha 710.67 \mathrm{~b} \mathrm{D}$ & $\alpha 950.60 \mathrm{C}$ & $\alpha 1184.45 \mathrm{AB}$ & $\alpha 1026.54 \mathrm{a} \mathrm{BC}$ & $\alpha 1281.00 \mathrm{a} \mathrm{A}$ \\
\hline \multicolumn{7}{|c|}{$\mathrm{H}$} \\
\hline \multirow{2}{*}{ Without Azospirillum } & 0 & $\beta 22.11 \mathrm{BC}$ & $\beta 22.33 \mathrm{BC}$ & $\beta 24.5 \mathrm{AB}$ & $\alpha 27 \mathrm{~A}$ & $\beta 19.44 \mathrm{C}$ \\
\hline & 50 & $\alpha 26.61 \mathrm{~A}$ & $\alpha 27.72 \mathrm{~A}$ & $\alpha 29.5 \mathrm{a} \mathrm{A}$ & $\beta 22.08 \mathrm{~b} \mathrm{~B}$ & $\alpha 23.16$ b B \\
\hline \multirow{2}{*}{ With Azospirillum } & 0 & $\beta 18.77 \mathrm{~B}$ & $\beta 22.22 \mathrm{~B}$ & $26.78 \mathrm{~A}$ & $\beta 23.11 \mathrm{AB}$ & $\beta 21.44 \mathrm{~B}$ \\
\hline & 50 & $\alpha 26.41 \mathrm{~A}$ & $\alpha 26.27 \mathrm{~A}$ & $26.41 \mathrm{~b} \mathrm{~A}$ & $\alpha 25.61$ a A & $\alpha 26.27$ a A \\
\hline
\end{tabular}

*Different uppercase letters in the row and different lowercase letters in the column indicate difference between treatments at $5 \%$ probability level by the Duncan test. ${ }^{* *}$ Different Greek letters in the column represent the difference between nitrogen doses for each level of inoculation and grazing management.

Table 4. Dry mass of green leaf blades (DMGL, $\mathrm{kg} \mathrm{ha}^{-1}$ ), dry mass of stems (DMS, $\mathrm{kg} \mathrm{ha}^{-1}$ ), dry mass of senescent material (DMSM, kg ha ${ }^{-1}$ ), dry mass of inflorescence (DMI, $\mathrm{kg} \mathrm{ha}^{-1}$ ), total dry mass (TDM), leaf/stem ratio (LSR), and height (H, $\mathrm{cm}$ ) of a pasture of black oat and ryegrass under different managements in a crop-livestock integration system (entry of the second grazing, year 2013).

\begin{tabular}{|c|c|c|c|c|c|}
\hline \multicolumn{6}{|c|}{ Dry mass of green leaves (DMGL) } \\
\hline \multicolumn{2}{|c|}{ Grazing management } & \multicolumn{2}{|c|}{$\mathrm{N}$ doses } & \multicolumn{2}{|c|}{ Inoculation } \\
\hline$\overline{\mathrm{CG}}$ & $408.29 \mathrm{c}^{*}$ & $0 \mathrm{~kg}$ of $\mathrm{N} \mathrm{ha}^{-1}$ & $441.23 \mathrm{~b}$ & With Azospirillum & 504.23 \\
\hline 30 & $690.47 \mathrm{a}$ & $50 \mathrm{~kg}$ of $\mathrm{N} \mathrm{ha}^{-1}$ & $438.14 \mathrm{~b}$ & Without Azospirillum & 514.90 \\
\hline 20 & $490.38 \mathrm{~b}$ & $100 \mathrm{~kg}$ of $\mathrm{Na}^{-1}$ & $649.33 \mathrm{a}$ & & \\
\hline 10 & $449.11 \mathrm{bc}$ & & & & \\
\hline
\end{tabular}

*Different uppercase letters in the row and different lowercase letters in the column indicate difference between treatments at $5 \%$ probability level by the Duncan test. ${ }^{*}$ Greek letters in the column represent the difference between nitrogen doses for each level of inoculation and grazing management. 
Table 4. Continuation.

\begin{tabular}{|c|c|c|c|c|c|}
\hline \multicolumn{6}{|c|}{ Dry mass of green leaves (DMGL) } \\
\hline \multicolumn{2}{|c|}{ Grazing management } & \multicolumn{2}{|c|}{$\mathrm{N}$ doses } & \multicolumn{2}{|c|}{ Inoculation } \\
\hline \multicolumn{6}{|c|}{ DMS } \\
\hline \multirow[t]{2}{*}{ Inoculation } & \multirow{2}{*}{$\begin{array}{c}\mathrm{N} \text { doses } \\
\left(\mathrm{kg} \text { of } \mathrm{N} \mathrm{ha}^{-1}\right)\end{array}$} & \multicolumn{4}{|c|}{ Grazing management } \\
\hline & & $\mathrm{CG}$ & $30 \mathrm{~cm}$ & $20 \mathrm{~cm}$ & $10 \mathrm{~cm}$ \\
\hline \multirow{3}{*}{ Without Azospirillum } & 0 & $* * \beta 182.52 \mathrm{D}$ & $\beta 961.62 \mathrm{~A}$ & $\beta 538.65 \mathrm{~B}$ & $354.40 \mathrm{C}$ \\
\hline & 50 & $\beta 220.59 \mathrm{C}$ & $\alpha 1637.01 \mathrm{a} \mathrm{A}$ & $\alpha 813.25$ a B & $366.66 \mathrm{C}$ \\
\hline & 100 & $\alpha 426.17 \mathrm{C}$ & $\alpha 1529.32$ a A & $\alpha 820.41 \mathrm{~B}$ & $306.15 \mathrm{C}$ \\
\hline \multirow{3}{*}{ With Azospirillum } & 0 & $\beta 178.97 \mathrm{C}$ & $\alpha 1037.09 \mathrm{~A}$ & $\alpha 674.59 \mathrm{~B}$ & $\beta 223.09 \mathrm{C}$ \\
\hline & 50 & $\beta 223.50 \mathrm{C}$ & $\beta 812.65$ b A & $\beta 409.88$ b B & $\alpha \beta 375.23 \mathrm{BC}$ \\
\hline & 100 & $\alpha 448.64 \mathrm{C}$ & $\beta 834.07 \mathrm{~b} \mathrm{~A}$ & $\alpha 668.53 \mathrm{~B}$ & $\alpha 442.98 \mathrm{C}$ \\
\hline \multicolumn{6}{|c|}{ DMSM } \\
\hline \multirow{3}{*}{ Without Azospirillum } & 0 & $37.91 \mathrm{BC}$ & $\beta 102.12 \mathrm{~A}$ & $\alpha \beta 95.30 \mathrm{AB}$ & $\beta 19.33 \mathrm{C}$ \\
\hline & 50 & $11.81 \mathrm{~B}$ & $\alpha \beta 142.34$ b A & $\alpha 58.77 \mathrm{~B}$ & $\alpha 125.39$ a A \\
\hline & 100 & $29.09 \mathrm{~B}$ & $\alpha 190.13 \mathrm{~A}$ & $\alpha 146.32$ a A & $\beta \quad 17.54 \mathrm{~B}$ \\
\hline \multirow{3}{*}{ With Azospirillum } & 0 & $19.15 \mathrm{~B}$ & $\beta 134.09 \mathrm{~A}$ & $\alpha 146.30 \mathrm{~A}$ & $13.40 \mathrm{~B}$ \\
\hline & 50 & $58.01 \mathrm{~B}$ & $\alpha 307.01$ a $\mathrm{A}$ & $\beta 77.42 \mathrm{~B}$ & $38.96 \mathrm{~b} \mathrm{~B}$ \\
\hline & 100 & $14.32 \mathrm{~B}$ & $\beta 158.14 \mathrm{~A}$ & $\beta 41.41 \mathrm{~b} \mathrm{~B}$ & $17.94 \mathrm{~B}$ \\
\hline \multicolumn{6}{|c|}{ DMI } \\
\hline \multirow{3}{*}{ Without Azospirillum } & 0 & $11.48 \mathrm{~A}$ & $\pi 53.18 \mathrm{~b} \mathrm{~A}$ & $\beta 31.34 \mathrm{~A}$ & $31.52 \mathrm{~A}$ \\
\hline & 50 & $11.32 \mathrm{C}$ & $\alpha 299.08$ a A & $\alpha 112.64$ a B & $18.86 \mathrm{C}$ \\
\hline & 100 & $5.45 \mathrm{~B}$ & $\beta 208.42$ a A & $\beta 35.57 \mathrm{~B}$ & $11.45 \mathrm{~B}$ \\
\hline \multirow{3}{*}{ With Azospirillum } & 0 & $9.35 \mathrm{~B}$ & $\alpha 195.83$ a A & $20.92 \mathrm{~B}$ & $12.26 \mathrm{~B}$ \\
\hline & 50 & 26.38 & $\beta 44.51 \mathrm{~b}$ & $30.52 \mathrm{~b}$ & 27.12 \\
\hline & 100 & 31.10 & $\beta 50.03 \mathrm{~b}$ & 54.29 & 41.80 \\
\hline \multicolumn{6}{|c|}{ TDM } \\
\hline \multirow[t]{3}{*}{ Without Azospirillum } & 0 & $\beta 446.87 \mathrm{C}$ & $\beta 1805.48 \mathrm{~b} \mathrm{~A}$ & $\pi 943.67 \mathrm{~b} \mathrm{~B}$ & $880.16 \mathrm{~B}$ \\
\hline & 50 & $\beta 558.47 \mathrm{C}$ & $\alpha 2731.24$ a A & $\beta 1453.89$ a B & $731.76 \mathrm{C}$ \\
\hline & 100 & $\alpha 1055.35 \mathrm{C}$ & $\alpha 2782.08 \mathrm{a} \mathrm{A}$ & $\alpha 1721.33$ a B & $892.00 \mathrm{C}$ \\
\hline \multirow{3}{*}{ With Azospirillum } & 0 & $\beta 570.00 \mathrm{C}$ & $\alpha 2058.65$ a A & $\alpha 1322.56$ a B & $\beta 649.96 \mathrm{~b} \mathrm{C}$ \\
\hline & 50 & $\beta 746.00 \mathrm{~B}$ & $\beta 1738.21 \mathrm{~b} \mathrm{~A}$ & $\beta 875.43$ b B & $\alpha 897.47$ a B \\
\hline & 100 & $\alpha 1114.66 \mathrm{BC}$ & $\alpha 1987.66 \mathrm{~b} \mathrm{~A}$ & $\alpha 1332.11 \mathrm{~b} \mathrm{~B}$ & $\alpha 966.66$ a C \\
\hline \multicolumn{6}{|c|}{$\mathrm{H}$} \\
\hline \multirow[t]{3}{*}{ Without Azospirillum } & 0 & 18.00 a C & $47.00 \mathrm{~A}$ & $\beta 43.5 \mathrm{~A}$ & $\beta 29.77 \mathrm{~B}$ \\
\hline & 50 & $18.00 \mathrm{D}$ & $51.22 \mathrm{~b} \mathrm{~A}$ & $\alpha \beta 46.5 \mathrm{~B}$ & $\alpha \beta 31.55 \mathrm{C}$ \\
\hline & 100 & $19.89 \mathrm{C}$ & $48.66 \mathrm{~b} \mathrm{~A}$ & $\alpha 49.5 \mathrm{~A}$ & $\alpha 35.89 \mathrm{~B}$ \\
\hline \multirow{3}{*}{ With Azospirillum } & 0 & $\beta 13.33 \mathrm{~b} \mathrm{D}$ & $\pi 50.44 \mathrm{~A}$ & $\beta 41.83 \mathrm{~B}$ & $32.33 \mathrm{C}$ \\
\hline & 50 & $\beta 16.88 \mathrm{D}$ & $\beta 59.5$ a A & $\beta 43.16 \mathrm{~B}$ & $31.00 \mathrm{C}$ \\
\hline & 100 & $\alpha 22.11 \mathrm{D}$ & $\alpha 66.67$ a A & $\alpha 48.66 \mathrm{~B}$ & $34.11 \mathrm{C}$ \\
\hline \multicolumn{6}{|c|}{ LSR } \\
\hline \multicolumn{2}{|c|}{ Grazing management } & $\mathrm{N}$ doses $(\mathrm{k}$ & $\left.\mathrm{f} \mathrm{N} \mathrm{ha}^{-1}\right)$ & Inoculati & \\
\hline $\mathrm{CG}$ & $1.51 \mathrm{a}$ & 0 & 1.16 & With Azospirillum & 1.12 \\
\hline 30 & $0.77 \mathrm{~b}$ & 50 & 0.95 & Without Azospirillum & 1.02 \\
\hline 20 & $0.65 \mathrm{~b}$ & 100 & 1.11 & & \\
\hline 10 & $1.37 \mathrm{a}$ & & & & \\
\hline
\end{tabular}

*Different uppercase letters in the row and different lowercase letters in the column indicate difference between treatments at $5 \%$ probability level by the Duncan test. ${ }^{* *}$ Greek letters in the column represent the difference between nitrogen doses for each level of inoculation and grazing management. 
M. S. BRUM et al.

Table 5. Dry mass of green leaf blades (DMGL, $\mathrm{kg} \mathrm{ha}^{-1}$ ), dry mass of stems (DMS, $\mathrm{kg} \mathrm{ha}^{-1}$ ), dry mass of senescent material (DMSM, $\mathrm{kg} \mathrm{ha}^{-1}$ ), dry mass of inflorescence (DMI, $\mathrm{kg} \mathrm{ha}^{-1}$ ), total dry mass (TDM), leaf/stem ratio (LSR), and height $(\mathrm{H}, \mathrm{cm})$ of a pasture of black oat and ryegrass under different managements in a crop-livestock integration system (entry of the third grazing, year 2013).

\begin{tabular}{|c|c|c|c|c|c|c|}
\hline \multicolumn{7}{|c|}{ DMGL } \\
\hline \multirow[t]{2}{*}{ Inoculation } & \multirow{2}{*}{$\begin{array}{c}\mathrm{N} \text { doses } \\
\left(\mathrm{kg}^{\circ} \mathrm{N} \mathrm{ha}^{-1}\right)\end{array}$} & \multicolumn{5}{|c|}{ Grazing Management } \\
\hline & & $\mathrm{CG}$ & $30 \mathrm{~cm}$ & $20 \mathrm{~cm}$ & $10 \mathrm{~cm}$ & No grazing \\
\hline \multirow{3}{*}{ Without Azospirillum } & 0 & $89.33 \mathrm{~B}$ & $* * \beta 61.77 \mathrm{~b} \mathrm{~B}$ & $*_{\alpha} 207.50 \mathrm{~A}$ & $\alpha \beta 140.53 \mathrm{AB}$ & $\beta 66.50 \mathrm{~B}$ \\
\hline & 50 & $58.66 \mathrm{~B}$ & $\beta 117.87 \mathrm{~B}$ & $\beta 92.22 \mathrm{~B}$ & $\alpha 213.27 \mathrm{~A}$ & $\alpha \beta 123.75 \mathrm{~B}$ \\
\hline & 100 & $67.63 \mathrm{~b} \mathrm{C}$ & $\alpha 206.67 \mathrm{~A}$ & $\alpha 221.78 \mathrm{~A}$ & $\beta 119.13$ b BC & $\alpha 151.10 \mathrm{~b} \mathrm{AB}$ \\
\hline \multirow{3}{*}{ With Azospirillum } & 0 & $\beta 34.00 \mathrm{C}$ & $155.47 \mathrm{a} \mathrm{AB}$ & $194.47 \mathrm{~A}$ & $\pi 68.02 \mathrm{C}$ & $\beta 91.94 \mathrm{BC}$ \\
\hline & 50 & $\beta 75.18 \mathrm{C}$ & $190.72 \mathrm{~B}$ & 150. $03 \mathrm{CB}$ & $\beta 282.32 \mathrm{~A}$ & $\beta 147.88 \mathrm{CB}$ \\
\hline & 100 & $\alpha 150.62$ a B & $171.44 \mathrm{~B}$ & $213.20 \mathrm{~B}$ & $\alpha 436.20 \mathrm{a} \mathrm{A}$ & $\alpha 431.47 \mathrm{a} \mathrm{A}$ \\
\hline \multicolumn{7}{|c|}{ DMS } \\
\hline \multirow{3}{*}{ Without Azospirillum } & 0 & $158.00 \mathrm{D}$ & $\beta 916.75 \mathrm{~b} \mathrm{~B}$ & $640.36 \mathrm{BC}$ & $\alpha \beta 379.39 \mathrm{CD}$ & $\beta 1521.38 \mathrm{~A}$ \\
\hline & 50 & $20.00 \mathrm{C}$ & $\beta 625.86 \mathrm{~B}$ & $817.96 \mathrm{~B}$ & $\alpha 511.18 \mathrm{~B}$ & $\beta 1794.50 \mathrm{~b} \mathrm{~A}$ \\
\hline & 100 & $51.63 \mathrm{D}$ & $\alpha 1373.44 \mathrm{~B}$ & $725.44 \mathrm{C}$ & $\alpha 385.76 \mathrm{CD}$ & $\alpha 2840.52 \mathrm{~A}$ \\
\hline \multirow{3}{*}{ With Azospirillum } & 0 & $30.00 \mathrm{C}$ & 747.38 a B & $526.90 \mathrm{~B}$ & $435.55 \mathrm{BC}$ & $\beta 1550.11 \mathrm{~A}$ \\
\hline & 50 & $178.10 \mathrm{C}$ & $975.74 \mathrm{~B}$ & 849.44 B & $331.78 \mathrm{C}$ & $\alpha 3016.18$ a A \\
\hline & 100 & $360.45 \mathrm{C}$ & $1036.33 \mathrm{~B}$ & $831.02 \mathrm{~B}$ & $626.23 \mathrm{BC}$ & $\alpha 2817.10 \mathrm{~A}$ \\
\hline \multicolumn{7}{|c|}{ DMSM } \\
\hline \multirow{3}{*}{ Without Azospirillum } & 0 & $142.66 \mathrm{~B}$ & $180.84 \mathrm{~B}$ & $\beta 72.48 \mathrm{~b} \mathrm{~B}$ & $109.87 \mathrm{~B}$ & $\beta 406.46 \mathrm{~A}$ \\
\hline & 50 & $156.00 \mathrm{CB}$ & $212.14 \mathrm{~B}$ & $\beta 86.43$ b CD & $16.79 \mathrm{D}$ & $\beta 413.84$ a A \\
\hline & 100 & $71.09 \mathrm{~b} \mathrm{C}$ & $116.66 \mathrm{~b} \mathrm{C}$ & $\alpha 384.78 \mathrm{~B}$ & $109.99 \mathrm{C}$ & $\alpha 674.00 \mathrm{~A}$ \\
\hline \multirow{3}{*}{ With Azospirillum } & 0 & $\beta 108 \mathrm{C}$ & $256.46 \mathrm{~B}$ & $\beta 244.96$ a B & $32.51 \mathrm{C}$ & $\alpha 498.34 \mathrm{~A}$ \\
\hline & 50 & $\beta 167.54 \mathrm{~B}$ & $259.29 \mathrm{AB}$ & $\alpha \beta 328.22$ a A & $16.17 \mathrm{C}$ & $\beta 281.01 \mathrm{~b} \mathrm{~A}$ \\
\hline & 100 & $\alpha 471.47 \mathrm{a} \mathrm{A}$ & $248.78 \mathrm{a} \mathrm{C}$ & $\alpha 368.11 \mathrm{~B}$ & $22.26 \mathrm{D}$ & $\alpha 567.44 \mathrm{~A}$ \\
\hline \multicolumn{7}{|c|}{ DMI } \\
\hline \multirow{3}{*}{ Without Azospirillum } & 0 & $14.00 \mathrm{D}$ & $548.41 \mathrm{~B}$ & $\beta 321.81 \mathrm{C}$ & $157.94 \mathrm{CD}$ & $\beta 965.89 \mathrm{~A}$ \\
\hline & 50 & $4.00 \mathrm{D}$ & $487.16 \mathrm{~B}$ & $\beta 330.38 \mathrm{CB}$ & $215.11 \mathrm{C}$ & $\beta 1048.44 \mathrm{~b} \mathrm{~A}$ \\
\hline & 100 & $13.82 \mathrm{C}$ & $879.25 \mathrm{~B}$ & $\alpha 723.07 \mathrm{~B}$ & $173.90 \mathrm{C}$ & $\alpha 1133.11 \mathrm{~b} \mathrm{~A}$ \\
\hline \multirow{3}{*}{ With Azospirillum } & 0 & $\beta 14.00 \mathrm{C}$ & $601.34 \mathrm{~A}$ & $\beta 320.93 \mathrm{~B}$ & $250.07 \mathrm{~B}$ & $\alpha 797.95 \mathrm{~A}$ \\
\hline & 50 & $\beta 53.18 \mathrm{C}$ & $506.24 \mathrm{~B}$ & $\alpha \beta 219.67 \mathrm{C}$ & $149.25 \mathrm{C}$ & $\beta 1542.92$ a A \\
\hline & 100 & $\alpha 117.27 \mathrm{C}$ & $684.87 \mathrm{~B}$ & $\alpha 702.93 \mathrm{~B}$ & $184.05 \mathrm{C}$ & $\alpha 2490.00 \mathrm{a} \mathrm{A}$ \\
\hline \multicolumn{7}{|c|}{ TDM } \\
\hline \multirow{3}{*}{ Without Azospirillum } & 0 & $404.00 \mathrm{D}$ & $\beta 1707.78 \mathrm{~B}$ & $\beta 1242.16 \mathrm{C}$ & $687.41 \mathrm{D}$ & $\pi 2960.24 \mathrm{~A}$ \\
\hline & 50 & $238.66 \mathrm{D}$ & $\beta 1443.05$ b B & $\beta 1327.00 \mathrm{~B}$ & $822.00 \mathrm{C}$ & $\beta 3380.54 \mathrm{~b} \mathrm{~A}$ \\
\hline & 100 & 204.18 b E & $\alpha 2576.03$ a B & $\alpha 2055.08 \mathrm{C}$ & $788.79 \mathrm{~b} \mathrm{D}$ & $\alpha 5660.34 \mathrm{~b} \mathrm{~A}$ \\
\hline \multirow{3}{*}{ With Azospirillum } & 0 & $\beta 186.00 \mathrm{D}$ & $\beta 1472.99 \mathrm{~B}$ & $\beta 1287.28 \mathrm{~B}$ & $\beta 833.62 \mathrm{C}$ & $\pi 2938.36 \mathrm{~A}$ \\
\hline & 50 & $\beta 474.00 \mathrm{E}$ & $\alpha 1932.00$ a B & $\beta 1547.38 \mathrm{C}$ & $\beta 779.54 \mathrm{D}$ & $\beta 4988.00$ a A \\
\hline & 100 & $\alpha 1099.82 \mathrm{aC}$ & $\alpha 1898.00 \mathrm{~b} \mathrm{~B}$ & $\alpha 2115.26 \mathrm{~B}$ & $\alpha 1268.74$ a C & $\alpha 6306.01 \mathrm{a} \mathrm{A}$ \\
\hline \multicolumn{7}{|c|}{ LSR } \\
\hline \multirow{3}{*}{ Without Azospirillum } & 0 & $\pi 0.58 \mathrm{~b} \mathrm{~A}$ & $0.06 \mathrm{~A}$ & $0.32 \mathrm{~A}$ & $0.36 \mathrm{~A}$ & $0.04 \mathrm{~A}$ \\
\hline & 50 & $\alpha 3.51 \mathrm{a} \mathrm{A}$ & $0.20 \mathrm{~b} \mathrm{~B}$ & $0.11 \mathrm{~B}$ & $0.45 \mathrm{~B}$ & $0.07 \mathrm{~B}$ \\
\hline & 100 & $\beta 1.37 \mathrm{a} \mathrm{A}$ & $0.15 \mathrm{~B}$ & $0.31 \mathrm{~B}$ & $0.32 \mathrm{~B}$ & $0.06 \mathrm{~B}$ \\
\hline & 0 & $\alpha 1.16$ a $\mathrm{A}$ & $0.22 \mathrm{~B}$ & $0.37 \mathrm{~B}$ & $\beta 0.16 \mathrm{~B}$ & $0.06 \mathrm{~B}$ \\
\hline With Azospirillum & 50 & $\beta 0.41 \mathrm{~b} \mathrm{AB}$ & 0.19 a B & $0.18 \mathrm{~B}$ & $\alpha 0.88 \mathrm{~A}$ & $0.05 \mathrm{~B}$ \\
\hline & 100 & $\beta 0.55 \mathrm{~b} \mathrm{~A}$ & $0.16 \mathrm{~A}$ & $0.27 \mathrm{~A}$ & $\alpha 0.69 \mathrm{~A}$ & $0.15 \mathrm{~A}$ \\
\hline & & & $\mathrm{H}$ & & & \\
\hline Without $4-0$ snirillun & 0 & $\alpha \beta 23.77 \mathrm{D}$ & $\beta 32.83 \mathrm{~b} \mathrm{~B}$ & $\alpha \beta 38.33 \mathrm{~b} \mathrm{~A}$ & $\beta 28.00 \mathrm{~b} \mathrm{C}$ & \\
\hline Without Azospirllum & 50 & $\beta 23.33 \mathrm{~b} \mathrm{C}$ & $\alpha 46.83$ a A & $\beta 36.00 \mathrm{~B}$ & $\beta 24.33 \mathrm{~b} \mathrm{C}$ & \\
\hline & 100 & $\alpha 27.66 \mathrm{D}$ & $\alpha 47.89 \mathrm{a} \mathrm{A}$ & $\alpha 40.89$ a B & $\alpha 36.55 \mathrm{C}$ & \\
\hline & 0 & $27.55 \mathrm{C}$ & $42.5 \mathrm{a} \mathrm{A}$ & $\alpha 43.66$ a A & $33.00 \mathrm{a} \mathrm{B}$ & \\
\hline With Azospirillum & 50 & $27.50 \mathrm{a} \mathrm{C}$ & $41.16 \mathrm{~b} \mathrm{~A}$ & $\beta 36.55 \mathrm{~B}$ & 30.89 a C & \\
\hline & 100 & $30.33 \mathrm{~B}$ & $40.50 \mathrm{~b} \mathrm{~A}$ & $\alpha 43.55 \mathrm{~b} \mathrm{~A}$ & $32.55 \mathrm{~B}$ & \\
\hline
\end{tabular}

*Different uppercase letters in the row and different lowercase letters in the column indicate difference between treatments at $5 \%$ probability level by the Duncan test. ${ }^{*}$ Greek letters in the column represent the difference between nitrogen doses for each level of inoculation and grazing management. 
There was no triple interaction for the pasture management heights, at the exit of the animals from the first grazing (Data not presented). These heights were different only according to grazing management, but the values were below those desired. This occurred because of the delay of the pasture, under corn residues, in reaching a forage mass close to $1,500 \mathrm{~kg}$ of $\mathrm{DM} \mathrm{ha} \mathrm{h}^{-1}$. For the pasture heights at the exit of the animals in the second grazing, there was triple interaction and the heights were closer to the desired heights.

It was verified that the differences of DMGL and residual TDM were more pronounced between the grazing management heights $(10,20$ and $30 \mathrm{~cm})$ when $50 \mathrm{~kg}$ of $\mathrm{N} \mathrm{ha}^{-1}$ were used, since the DMGL and TDM of the pasture before the entry of the grazing animals were higher due to nitrogen fertilization, allowing greater differences to be observed at different heights after grazing (Data not presented), which was also verified for DMGL and residual TDM after the second grazing (Data not presented), when more significant differences between the grazing management heights were obtained when the pasture received fertilization of $100 \mathrm{~kg} \mathrm{ha}^{-1}$ of $\mathrm{N}$ for residual DMGL and fertilization of 50 and $100 \mathrm{~kg} \mathrm{ha}^{-1}$ of $\mathrm{N}$ for TDM.

There was a triple interaction for the DMP of the pasture under corn residues (Table 6). As for grazing management, there was higher pasture production in the treatment without grazing and in the treatment $30 \mathrm{~cm}$. It is possible to infer that the increase in pasture height results in an increase in forage mass. As a consequence, a larger leaf area is maintained in these treatments, increasing the ability of plants to intercept radiation and accumulate biomass.

Table 6. Total dry mass production (DMP, $\mathrm{kg} \mathrm{ha}^{-1}$ ) in black oat and ryegrass pasture under corn residues in a crop-livestock integration system (Year - 2013).

\begin{tabular}{cccccc}
\hline \multicolumn{5}{c}{ Total dry mass production (DMP) } \\
\hline Inoculation & $\begin{array}{c}\mathrm{N} \text { doses } \\
\left(\mathrm{kg} \mathrm{of} \mathrm{N} \mathrm{ha}^{-1}\right)\end{array}$ & $30 \mathrm{~cm}$ & $20 \mathrm{~cm}$ & $10 \mathrm{~cm}$ & No grazing \\
\hline Without Azospirillum & 0 & $3089.46 \mathrm{~A}$ & $* * \beta 1917.46 \mathrm{~B}$ & $2469.45 \mathrm{AB}$ & $\beta 2960.24 \mathrm{~A}$ \\
& 50 & $3117.22 \mathrm{~A}$ & $\beta 2291.11 \mathrm{~B}$ & $2098.34 \mathrm{~b} \mathrm{~B}$ & $\beta 3380.54 \mathrm{~b} \mathrm{~A}$ \\
& 100 & $3578.62 \mathrm{~B}$ & $\alpha 3557.39 \mathrm{~B}$ & $2194.71 \mathrm{~b} \mathrm{C}$ & $\alpha 5660.34 \mathrm{~A}$ \\
\hline With Azospirillum & 0 & $\alpha \beta 3205.81 \mathrm{~A}$ & $* \pi 1680.50 \mathrm{~B}$ & $\pi 2072.46 \mathrm{~B}$ & $\pi 2938.36 \mathrm{~A}$ \\
& 50 & $\beta 2633.08 \mathrm{~B}$ & $\beta 2340.66 \mathrm{~B}$ & $\beta 2764.58 \mathrm{a} \mathrm{B}$ & $\beta 4988.00 \mathrm{a} \mathrm{A}$ \\
& 100 & $\alpha 3404.47 \mathrm{~B}$ & $\alpha 3764.06 \mathrm{~B}$ & $\alpha 3455.98 \mathrm{a} \mathrm{B}$ & $\alpha 6306.01 \mathrm{~A}$ \\
\hline
\end{tabular}

*Different uppercase letters in the row and different lowercase letters in the column indicate difference between treatments at $5 \%$ probability level by the Duncan test. ${ }^{* *}$ Greek letters in the column represent the difference between nitrogen doses for each level of inoculation and grazing management.

$\mathrm{N}$ doses had a distinct effect as a function of inoculation and grazing management. Without inoculation, at heights of 10 and $30 \mathrm{~cm}$, nitrogen application did not increase the total pasture production, and in grazing managements at $20 \mathrm{~cm}$ and without grazing, the pasture produced more when $100 \mathrm{~kg} \mathrm{ha}^{-1}$ of $\mathrm{N}$ were added. When considering Brachiaria plantaginea, the use of A. brasilense increased nitrogen accumulation in plant biomass in such a way to be equivalent to $40 \mathrm{~kg}$ of $\mathrm{N} \mathrm{ha}^{-1}$, which contributes to the recovery of degraded pastures and the addition of carbon in the soil (HUNGRIA; NOGUEIRA; ARAUJO, 2016).

Corn is a crop that has high demand for nitrogen and, after harvesting, little of this nitrogen remains in the soil. The $\mathrm{C} / \mathrm{N}$ ratio of corn is high, causing nitrogen release to be slow, which makes this nutrient less available at the beginning of the subsequent crop development (SILVA et al., 2009). Thus, the association of inoculation with $100 \mathrm{~kg} \mathrm{ha}^{-1}$ of $\mathrm{N}$ may have met the need for this nutrient, resulting in significant differences. Schaefer et al. (2019) and Brum et al. (2016) attributed the increase in grain yield, grain mass and shoot dry mass to the use of $A$. brasilense.

For inoculation, the total pasture production did not respond or responded positively according to grazing management and $\mathrm{N}$ doses. At height of 10 $\mathrm{cm}$ with 50 and $100 \mathrm{~kg}$ of $\mathrm{N} \mathrm{ha}^{-1}$ and in the absence of grazing (NG) with $50 \mathrm{~kg}$ of $\mathrm{N} \mathrm{ha}^{-1}$, the pasture produced more biomass when the seeds were inoculated. A probable explanation is the fact that diazotrophic bacteria do not contribute with sufficient amounts of fixed $\mathrm{N}$ to ensure maximum 
yield in non-legume plants (BALDANI; BALDANI, 2005). Furthermore, the absence of $\mathrm{N}$ may represent a high cost of the association for the plant, under a condition of low $\mathrm{N}$ level in the soil.

The production of growth-promoting substances and an increase in the rate of nutrient absorption due to inoculation with Azospirillum may explain the increase in yield. After inoculation with Azospirillum, there is a change in the morphology of plant roots, which has been attributed to the production of plant growth-regulating substances. There is also an increase in the root surface due to the increase in the number of lateral roots and root hairs. This results in greater absorption of water and nutrients, which is the main factor for increasing plant growth

\section{CONCLUSIONS}

The biomass production of black oat and ryegrass pasture increased with nitrogen application and inoculation of Azospirillum brasilense. The proportions of structural components varied as a function of different grazing managements, nitrogen doses and inoculation with Azospirillum brasilense. Azospirillum brasilense can be used as substitute of nitrogen fertilization in black oat-ryegrass intercropping in a crop-livestock integration system.

\section{REFERENCES}

AAZADI, M. S. et al. The Study Effect of Nitrogen, Azotobacter Spp. and Azospirillum Spp. on Phenological and Morphological Traits of Durum Wheat Cultivars in Dehloran Region, Iran. Cercetari Agronomice in Moldova, 47: 15-21, 2014.

AON, M. et al. Diazotrophic inoculation supplemented nitrogen demand of flooded rice under field conditions. Pakistan Journal of Agricultural Sciences, 52:145-150, 2015.

BAGGiO, C. et al. Padrões de uso do tempo por novilhos em pastagem consorciada de azevém anual e aveia-preta. Revista Brasileira de Zootecnia, 37: 1912-1918, 2008.

BALBINOT, A. A. et al. Integração lavourapecuária: intensificação de uso de áreas agrícolas. Ciência Rural, 39: 1925-1933, 2009.

BALDANI, J. I.; BALDANI, V. L. History on the biological nitrogen fixation research in graminaceous plants: special emphasis on the Brazilian experience. Anais da Academia Brasileira de Ciências, 77: 549-579, 2005.
BILAL, M. et al. Dry matter yield and forage quality traits of oat (Avena sativa L.) under integrative use of microbial and synthetic source of nitrogen. Journal of the Saudi Society of Agricultural Sciences, 16: 236-241, 2017.

BRUM, M. et al. Components of corn crop yield under inoculation with Azospirillum brasilense using integrated crop-livestock system. Acta Scientiarum. Agronomy, 38: 485-492, 2016.

CASSOL, L. C. et al. Produtividade e composição estrutural de aveia e azevém submetidos a épocas de corte e adubação nitrogenada. Revista Ceres, 58: 438-443, 2011.

DOMINGUES NETO, F. et al. Influência de Azospirillum brasilense no desenvolvimento vegetativo, produção de forragem e acúmulo de massa seca da aveia preta. Enciclopédia Biosfera, 10: 2013-2019, 2014.

EMBRAPA SOLOS - Empresa Brasileira de Pesquisa Agropecuária Sistema brasileiro de classificação de solos. EMBRAPA Produção de Informação, Brasília, p. 16, 2006.

FILGUEIRAS, L. M.; MENESES, C. H. Efeito das bactérias promotoras de crescimento de plantas na proteção contra o estresse hídrico. Journal of Biology \& Pharmacy and Agricultural Management, 11:21-30, 2015.

HUNGRIA, M.; NOGUEIRA, M.; ARAUJO, R. Soybean seed co-inoculation with Bradyrhizobium spp. and Azospirillum brasilense: a new biotechnological tool to improve yield and sustainability. American Journal of Plant Sciences, 6: 811-817, 2015.

HUNGRIA, M.; NOGUEIRA, M.; ARAUJO, R. Inoculation of Brachiaria spp. with the plant growthpromoting bacterium Azospirillum brasilense: an environment-friendly component in the reclamation of degraded pastures in the tropics. Agriculture, Ecosystems \& Environment, 221: 125-131, 2016.

KAZI, N. et al. The response of wheat genotypes to inoculation with Azospirillum brasilense in the field. Field Crops Research, 196: 368-378, 2016.

KUNRATH, T. R. et al. Management targets for continuously stocked mixed oat $\times$ annual ryegrass pasture in a no-till integrated crop-livestock system. European Journal of Agronomy, 57: 71$76,2014$.

KUREPIN, L.; ZAMAN, M.; PHARIS, R. Phytohormonal basis for the plant growth promoting 
action of naturally occurring biostimulators. Journal of the Science of Food and Agriculture, 94: 1715$1722,2014$.

MULLER, T. et al. Combination of inoculation methods of Azospirillum brasilense with broadcasting of nitrogen fertilizer increases corn yield. Ciência Rural, 46: 210-215, 2016

PELLEGRINI, L. et al. Produção e qualidade de azevém-anual submetido a adubação nitrogenada sob pastejo por cordeiros. Revista Brasileira de Zootecnia, 39: 1894-1904, 2010.

PICCININ, G. et al. Efficiency of seed inoculation with Azospirillum brasilense on agronomic characteristics and yield of wheat. Industrial Crops and Products, 43: 393-397, 2013.

SCHAEFER, P. et al. Inoculation with Azospirillum brasilense on corn yield and yield components in an integrated crop-livestock system. Acta Scientiarum. Agronomy, 41: e39481, 2019.

SILVA, P. C. et al. Fitomassa e relação $\mathrm{C} / \mathrm{N}$ em consórcios de sorgo e milho com espécies de cobertura. Pesquisa Agropecuária Brasileira, 44: 1504-1512, 2009.

SOUZA, E. D. et al. Soil aggregation in a croplivestock integration system under notillage. Revista Brasileira de Ciência do solo, 34 : 1365-1374, 2010.

WALKER, V. et al. Variation of secondary metabolite levels in maize seedling roots induced by inoculation with Azospirillum, Pseudomonas and Glomus consortium under field conditions. Plant and soil, 356: 151-163, 2012. 